\title{
Konferencja naukowo-szkoleniowa pod patronatem \\ Sekcji Schorzeń Pozapiramidowych \\ Polskiego Towarzystwa Neurologicznego
}

\section{Toksyna botulinowa w praktyce neurologicznej Botulinum Toxin in Neurological Practice}

\author{
17-18 września 2010 r., Hotel Nadmorski, Gdynia
}

Sponsorzy: Allergan/Ewopharma, Ipsen, Merz/Natur Produkt

17 września (piątek)

11.00-11.10 Rozpoczęcie konferencji i powitanie gości (prof. J. Sławek)

11.10-11.40 Wykład inauguracyjny: Od trucizny do leku: historia toksyny botulinowej (prof. T.M. Domżał)

Sesja 1. Farmakologia preparatów toksyny botulinowej: podobieństwa i różnice

Prowadzący: prof. T.M. Domżał, dr hab. H. Car

11.40-12.00 Preparaty toksyny botulinowej: podobieństwa i różnice farmakologiczne (dr hab. H. Car)

12.00-12.20 Mechanizm działania toksyny botulinowej - jak optymalizować efekty kliniczne? (prof. A. Bogucki)

12.20-12.40 Biorównoważność jednostek toksyny botulinowej: mity i fakty (prof. J. Sławek)

12.40-13.00 Czy leczenie toksyną botulinową jest bezpieczne? - update (prof. J. Sławek)

13.00-13.10 Dyskusja

13.10-14.00 Przerwa na lunch

Sesja 2. Toksyna botulinowa w leczeniu dystonii ogniskowych i segmentalnych oraz połowiczego kurczu twarzy

Prowadzący: prof. G. Opala, prof. A. Szczudlik

14.00-14.20 Kurcz powiek (prof. J. Sławek)

14.20-14.40 Dystonie twarzy i dystonia krtaniowa (prof. A. Friedman)
14.40-15.00 Połowiczy kurcz twarzy (dr med. M. Rudzińska)

15.00-15.20 Dystonia szyjna (dr med. S. Ochudło) 15.20-15.30 Dyskusja

15. 30-16.00 Przerwa na kawę

Sesja 3. Jak poprawić skuteczność leczenia dystonii ogniskowych?

Prowadzący: prof. A. Friedman, prof. A. Bogucki

16.00-16.30 Complexity of cervical dystonia - how to treat patients effectively? (prof. H. Hefter, Dusseldorf, Niemcy)

16.30-16.50 Wstrzykiwać pod kontrolą EMG czy wg punktów anatomicznych, wzorca kręczu, bólu? (dr med. M. Banach)

16.50-17.10 Immunogenność - czy nadal stanowi problem? (prof. A. Bogucki)

17.10-17.30 Jakość życia chorych z dystonią szyjną i kurczem powiek - wpływ leczenia toksyną botulinową (dr med. S. Ochudło)

17.30-17.40 Dyskusja

17.45-19.00 Warsztaty wideo: Dystonias - difficult cases. Video-review workshop (prof. D. Dressler, Hannover, Niemcy)

20.00 Wieczór towarzyski 
18 września (sobota)

9.00-9.40 Wykład specjalny: Complex treatment of spasticity in adults: the role of botulinum toxin and European Consensus 2009 Guidelines (prof. A. Ward, Stoke-on-Trent, UK)

\section{Sesja 1. Toksyna botulinowa w spastyczności} u dorosłych

Prowadzący: dr med. M. Rudzińska, dr M. Krawczyk

9.40-10.00 Epidemiologia spastyczności (prof. J. Sławek)

10.00-10.20 Leczenie toksyną botulinową spastyczności u dorosłych z punktu widzenia fizjoterapeuty (dr M. Krawczyk)

10.20-10.40 Toksyna botulinowa w leczeniu spastyczności kończyny górnej - update (dr med. M. Rudzińska)

10.40-11.00 Toksyna botulinowa w leczeniu spastyczności kończyny dolnej - update (dr med. D. Koziorowski)

11.00-11.10 Dyskusja

11.10-11.30 Przerwa na kawę

11.30-12.30 Warsztaty: Spasticity treatment with botulinum toxin - practical approach to common and difficult cases - video workshop (prof. A. Ward, Stoke-on-Trent, UK)

Sesja 2. Toksyna botulinowa w leczeniu spastyczności u dzieci

Prowadzący: prof. M. Jóźwiak, dr med. E. Pilarska

12.30-12.50 Czy toksyna botulinowa zmieniła podejście do fizjoterapii dzieci z mózgowym porażeniem dziecięcym? (mgr L. Klimont)
12.50-13.10 Wielopoziomowe leczenie spastyczności u dzieci z MPD (dr med. M. Bonikowski)

13.10-13.30 Zabiegi operacyjne, pompa baklofenowa czy/lub/i toksyna botulinowa? (prof. M. Jóźwiak)

13.30-13.50 Spastyczność kończyny górnej u dzieci - czy leczenie toksyną botulinową jest skuteczne? (dr med. A. Czernuszenko)

13.50-14.10 Rola toksyny botulinowej w leczeniu spastyczności u dzieci - Europejski Konsensus 2007 (dr med. M. Bonikowski)

14.10-14.20 Dyskusja

14.20-15.00 Przerwa na lunch

15.00-15.30 Warsztaty: Botulinum toxin in myofascial pain - workshop (prof. H. Hefter, Dusseldorf, Niemcy)

Sesja 3. Toksyna botulinowa - inne wskazania w neurologii

Prowadzący: dr med. B. Jasińska-Myga, dr med. S. Budrewicz

15.30-15.50 Leczenie nadpotliwości (prof. A. Bogucki)

15.50-16.10 Leczenie nadmiernego ślinienia (prof. A. Friedman)

16.10-16.30 Leczenie bólu (prof. T.M. Domżał)

16.30-16.50 Leczenie bólów głowy (dr hab. J.J. Rożniecki)

16.50-17.10 Leczenie pęcherza neurogennego (dr hab. P. Radziszewski)

17.10-17. 30 Leczenie drżenia (dr med. S. Budrewicz)

17.30-17.40 Dyskusja

17.40 Zakończenie konferencji (prof. J. Sławek)

Zgłoszenie uczestnictwa:

First Class S.A.

tel. $+48225787156,+48225787160$

e-mail: kongres@firstclass.com.pl

Opłata konferencyjna: $150 \mathrm{zł}$ 